\title{
Relating hygroscopicity and composition of organic aerosol particulate matter
}

\author{
J. Duplissy ${ }^{1, *}$, P. F. DeCarlo ${ }^{1,3}$, J. Dommen ${ }^{1}$, M. R. Alfarra ${ }^{2}$, A. Metzger $^{1,{ }^{* *}}$, I. Barmpadimos ${ }^{1}$, A. S. H. Prevot ${ }^{1}$, \\ E. Weingartner ${ }^{1}$, T. Tritscher ${ }^{1}$, M. Gysel ${ }^{1}$, A. C. Aiken $^{3, * * *}$, J. L. Jimenez ${ }^{3}$, M. R. Canagaratna ${ }^{4}$, D. R. Worsnop ${ }^{4,5}$, \\ D. R. Collins ${ }^{6}$, J. Tomlinson ${ }^{6,7}$, and U. Baltensperger ${ }^{1}$ \\ ${ }^{1}$ Laboratory of Atmospheric Chemistry, Paul Scherrer Institut, 5232 Villigen, Switzerland \\ ${ }^{2}$ National Centre for Atmospheric Science (NCAS), School of Earth, Atmospheric and Environmental Sciences, \\ The University of Manchester, Manchester, UK \\ ${ }^{3}$ Department of Chemistry and Biochemistry, and CIRES, University of Colorado, UCB 216, Boulder, CO 80309-0216, USA \\ ${ }^{4}$ Aerodyne Research, Billerica, MA, USA \\ ${ }^{5}$ Department of Physics, University of Helsinki, 000014, Helsinki, Finland \\ ${ }^{6}$ Department of Atmospheric Sciences, Texas A\&M University, 3150 TAMU, College Station, TX 77843-3150, USA \\ ${ }^{7}$ Pacific Northwest National Laboratory, Richland, WA 99352, USA \\ *now at: PH department, CERN, 1211, Geneva, Switzerland \\ ** now at: Institute for Atmospheric and Environmental Sciences, Goethe-University Frankfurt, Frankfurt am Main, Germany \\ **** now at: Los Alamos National Laboratory, Los Alamos, NM 87545, USA
}

Received: 19 July 2010 - Published in Atmos. Chem. Phys. Discuss.: 17 August 2010

Revised: 25 January 2011 - Accepted: 30 January 2011 - Published: 10 February 2011

\begin{abstract}
A hygroscopicity tandem differential mobility analyzer (HTDMA) was used to measure the water uptake (hygroscopicity) of secondary organic aerosol (SOA) formed during the chemical and photochemical oxidation of several organic precursors in a smog chamber. Electron ionization mass spectra of the non-refractory submicron aerosol were simultaneously determined with an aerosol mass spectrometer (AMS), and correlations between the two different signals were investigated. SOA hygroscopicity was found to strongly correlate with the relative abundance of the ion signal $\mathrm{m} / \mathrm{z} 44$ expressed as a fraction of total organic signal $\left(f_{44}\right) . m / z 44$ is due mostly to the ion fragment $\mathrm{CO}_{2}^{+}$for all types of SOA systems studied, and has been previously shown to strongly correlate with organic $\mathrm{O} / \mathrm{C}$ for ambient and chamber OA. The analysis was also performed on ambient OA from two field experiments at the remote site Jungfraujoch, and the megacity Mexico City, where similar results were found. A simple empirical linear relation between the hygroscopicity of OA at subsaturated $\mathrm{RH}$, as given by the hygroscopic growth factor $(\mathrm{GF})$ or " $\kappa_{\mathrm{org}}$ " parameter, and $f_{44}$ was determined and is given by $\kappa_{\mathrm{org}}=2.2 \times f_{44}-0.13$. This approximation can be further verified and refined as the
\end{abstract}

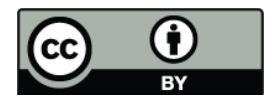

Correspondence to: J. Duplissy (jonathan.duplissy@ cern.ch) database for AMS and HTDMA measurements is constantly being expanded around the world. The use of this approximation could introduce an important simplification in the parameterization of hygroscopicity of OA in atmospheric models, since $f_{44}$ is correlated with the photochemical age of an air mass.

\section{Introduction}

The hygroscopic growth of atmospheric aerosol particles plays an important role in numerous atmospheric processes such as climate forcing, visibility degradation, cloud formation and heterogeneous chemistry. Atmospheric aerosol components can be classified into inorganic and organic fractions. Organic material, habitually referred to as organic aerosol (OA), often represents more than half of the mass for submicron particles (Jimenez et al., 2009). A substantial fraction of that is secondary OA (SOA) which is formed from chemical reactions of gaseous compounds (Zhang et al., 2007a). The hygroscopic properties of most inorganic salts present in atmospheric aerosol are well known. In contrast, OA is composed of thousands of individual species (Goldstein and Galbally, 2007). Of these, the hygroscopic properties have been investigated only for very few substances. Different approaches are used to determine the influence of OA

Published by Copernicus Publications on behalf of the European Geosciences Union. 
on the hygroscopic behavior of ambient aerosol under subsaturated relative humidity (RH) conditions. Previous laboratory studies, investigating the hygroscopic properties of organic model substances, have mostly focused on pure and mixed low molecular weight organic acids such as carboxylic acids, dicarboxylic acids, and multifunctional organic acids or their salts (Peng et al., 2001; Choi and Chan, 2002b), as well as on their mixtures with inorganic salts (Cruz and Pandis, 2000; Choi and Chan, 2002a; Hämeri et al., 2002). Theoretical models for the prediction of the hygroscopic growth of mixed organic and mixed inorganic/organic aerosols were recently introduced by several investigators (Clegg et al., 2001; Topping et al., 2005b). Treating individual compounds at the molecular level requires binary aqueous data for each compound (Saxena and Hildemann, 1997). The problem of characterizing activity coefficients in multiple-component organic solutions has been described previously and methods have been developed, the most widely used being UNIversal Functional Activity Coefficient (UNIFAC) (Fredenslund et al., 1975). Though UNIFAC has been noted to have various shortcomings (e.g. Choi and Chan, 2002b; Cruz and Pandis, 2000), numerous attempts to improve its predictive capability for components of atmospheric importance have been made. The difficulty in using these models to predict the hygroscopicity of a mixed organic aerosol (such as ambient organic aerosol) is that detailed input is required (e.g. the abundance of functional groups and the molecular weight of the organic components). Data of this kind are typically not available, nor is this information predicted by large scale atmospheric models.

The hygroscopic properties of SOA obtained by oxidation of anthropogenic and biogenic volatile organic precursors like aromatics or terpenes in smog chambers have also been investigated (Virkkula et al., 1999; Hegg et al., 2001; Shantz et al., 2003; Varutbangkul et al., 2006; Duplissy et al., 2008). Varutbangkul et al. (2006) showed that the SOA hygroscopicity is inversely proportional to the precursor molecular weight and SOA yield. Duplissy et al. (2008) showed that at higher precursor mixing ratios, which results in higher SOA concentrations, the hygroscopicity of the SOA is lower. They proposed that at higher concentration more volatile (and less oxidized) products partition into the particle phase, leading to a decrease of the hygroscopicity of the particle. In field studies, Gysel et al. (2007) and Sjogren et al. (2008) estimated the average hygroscopicity of bulk OA from ambient aerosol hygroscopicity. Cubison et al. (2006) reported, but did not quantify, an increase of the hygroscopicity of ambient aerosol when the OA became more oxidized.

Jimenez et al. (2009) have recently published a relationship between OA chemical composition and hygroscopicity. Here, this relationship as well as the underlying experiments are described in more detail and are complemented by further experiments. We measured the water uptake of aerosol particles at subsaturated RH with a hygroscopicity tandem differential mobility analyzer (HTDMA) (Liu et al., 1978). Par- allel measurements of the time and mass-weighted chemical composition of non-refractory submicron aerosol (including sulfate, nitrate, ammonium and OA) were performed with an aerosol mass spectrometer (AMS). The hygroscopic growth of OA was either directly determined for pure OA or, for mixtures of organic and inorganic aerosol, deduced from the hygroscopic growth measurements with the Zdanovskii-StokesRobinson (ZSR) relation (Stokes and Robinson, 1966) using the chemical composition obtained from the AMS (Gysel et al., 2007).

\section{Experimental}

\subsection{Smog chamber experiments}

The experiments were performed in the PSI smog chamber (Paulsen et al., 2005). The PSI smog chamber is a $27-\mathrm{m}^{3}$ transparent Teflon ${ }^{\circledR}$ (FEP) bag suspended in a temperaturecontrolled housing. The radiation was generated by four xenon arc lamps (4 kW each) selected to simulate the solar light spectrum and natural photochemistry. Before introduction of the precursors the chamber was humidified to $50 \%$ relative humidity. SOA was produced from three different precursors: 1,3,5-trimethylbenzene (TMB), $\alpha$-pinene and isoprene. The precursor concentrations were measured with a proton-transfer-reaction mass spectrometer. Two different sets of experiments were performed; (1) traditional photooxidation experiments and (2) ozonolysis of $\alpha$-pinene followed by oxidative ageing of the reaction mixture with $\mathrm{OH}$ radicals. The experimental conditions are summarized in Table 1 .

1. In the traditional photo-oxidation experiments an organic precursor and nitrogen oxides (ratio of 2 to 1 ) were introduced into the chamber and allowed to mix for approximately $30 \mathrm{~min}$ before the lights were turned on. The reaction of $\mathrm{OH}$ with $\mathrm{TMB}$ leads to formation of $\mathrm{RO}_{2}$ radicals, which rapidly convert $\mathrm{NO}$ to $\mathrm{NO}_{2}$. Ozone is formed from the photolysis of $\mathrm{NO}_{2}$, and its concentration increases rapidly after NO concentration has dropped. In the case of $\alpha$-pinene and isoprene the reaction of ozone also plays a role once the ozone concentration becomes high enough. In all these experiments the organic precursor did not react completely away. Thus, besides oxidative ageing of SOA first-generation oxidation products of the precursor were always condensing on the SOA.

2. In the ozonolysis and ageing experiments ozone (200$500 \mathrm{ppb}$ ) was first added to the humidified chamber. Then $\alpha$-pinene at a concentration of 10 or $40 \mathrm{ppb}$ was introduced. After all $\alpha$-pinene had reacted away by ozone, the reaction mixture was further oxidized by $\mathrm{OH}$ radicals in two different ways, called dark $\mathrm{OH}$ or $\mathrm{OH}+$ light. 
Table 1. Experimental conditions for SOA formed in the smog chamber.

\begin{tabular}{|c|c|c|c|c|c|}
\hline Experiment & Precursor [ppb] & $\begin{array}{r}\mathrm{NO} \\
{[\mathrm{ppb}]}\end{array}$ & $\begin{array}{c}\mathrm{NO}_{2} \\
{[\mathrm{ppb}]}\end{array}$ & $\begin{array}{r}\mathrm{O}_{3} \\
{[\mathrm{ppb}]}\end{array}$ & Remarks \\
\hline 1 & TMB 150 & - & 75 & & traditional photo-oxidation \\
\hline 2 & TMB 86 & - & 43 & & traditional photo-oxidation \\
\hline 3 & $\alpha$-pinene 180 & 48 & 60 & & traditional photo-oxidation \\
\hline 4 & $\alpha$-pinene 124 & 31 & 41 & & traditional photo-oxidation \\
\hline $5^{*}$ & $\alpha$-pinene 10 & - & 5 & & traditional photo-oxidation \\
\hline 6 & isoprene 1200 & 300 & 300 & & traditional photo-oxidation \\
\hline $7^{1}$ & $\alpha$-pinene 10 & & & $200-500$ & ozonolysis \\
\hline $8^{2}$ & $\alpha$-pinene 40 & & & $110-500$ & ozonolysis \\
\hline $9^{3}$ & $\alpha$-pinene 10 & - & - & & $\mathrm{OH}$ exposure of mixture exp 7 \\
\hline $10^{4}$ & $\alpha$-pinene 40 & - & - & & $\mathrm{OH}$ exposure of mixture exp 8 \\
\hline
\end{tabular}

\footnotetext{
* Experiment 5 is a combination of two similar experiments where the AMS and HTDMA were not measuring simultaneously.

1 six similar ozonolysis experiments

2 three similar ozonolysis experiments

3 five similar experiments with $\mathrm{OH}+$ light or dark $\mathrm{OH}$

4 three similar experiments with $\mathrm{OH}+$ light or dark $\mathrm{OH}$
}

For the dark OH, ozone was added to obtain about 500$700 \mathrm{ppb}$ in the chamber. Then tetramethylethylene was continuously flushed into the chamber where it reacted with ozone and produced $\mathrm{OH}$ radicals in high yields. For the $\mathrm{OH}+$ light, HONO was flushed into the chamber until it reached approximately $10 \mathrm{ppb}$. Then lights were turned on and photolysis of $\mathrm{HONO}$ produced $\mathrm{OH}$ radicals. HONO was continuously replenished to provide a semi-constant $\mathrm{OH}$ source.

\subsection{Field measurements}

Field measurements were performed at the high-alpine site Jungfraujoch, Switzerland and in Mexico City.

The Jungfraujoch is a European high-alpine background site located on an exposed mountain ridge in the Bernese Alps, Switzerland, at $3580 \mathrm{~m}$ altitude $\left(46.33^{\circ} \mathrm{N}, 7.59^{\circ} \mathrm{E}\right)$. Within the World Meteorological Organization (WMO) Global Atmosphere Watch (GAW) program continuous measurements of aerosol parameters have been performed at the JFJ site since 1995 (Collaud Coen et al., 2007). The station is surrounded by glaciers and rocks, and no local vegetation is present. An Aerodyne quadrupole AMS and an HTDMA were deployed at the Jungfraujoch research station. Hygroscopicity measurements have been performed during the Cloud and Aerosol Characterization Experiment (CLACE3) (Sjogren et al., 2008).

The measurements in Mexico City were part of the Megacity Initiative: Local and Global Research Observations (MILAGRO) and took place in and around Mexico City during March 2006. The MILAGRO campaign was designed to study the chemical characterization and transformation of pollutants from the Mexico City urban area to regional and global scales. A high resolution time-offlight aerosol mass spectrometer (HR-ToF-AMS) and an HTDMA were deployed on an aircraft platform onboard the $\mathrm{Na}$ tional Science Foundation/National Center for Atmospheric Research (NSF/NCAR) C-130 aircraft. Details on the deployment and results for the campaign are found in DeCarlo et al. $(2008,2010)$.

\subsection{HTDMA}

The hygroscopic properties of the various aerosol types were measured with a HTDMA. Briefly, a HTDMA functions as follows: a differential mobility analyzer selects a monodisperse aerosol size cut with mobility diameter, $D_{0}$, under dry conditions. The aerosol then passes through a humidifier with a controlled higher RH, and the size distribution over mobility diameter $D(\mathrm{RH})$ is measured with a second DMA coupled to a condensation particle counter (CPC). The hygroscopic growth factor $(\mathrm{GF}(\mathrm{RH}))$ indicates the relative increase in mobility diameter of particles due to water absorption at a certain RH, and is defined as:

$\mathrm{GF}(\mathrm{RH})=\frac{D(\mathrm{RH})}{D_{0}}$

In this study three different custom built HTDMAs were used. Specific details of HTDMA1, HTDMA2 and HTDMA3 can be found in Duplissy et al. (2008, 2009), Gasparini et al. (2004) and Sjogren et al. (2008) respectively. The residence times of the aerosol in the humidifier, the chosen $\mathrm{RH}$ and the operating temperature were $\left(15 \mathrm{~s}, 95 \%, 20^{\circ} \mathrm{C}\right)$, $\left(10 \mathrm{~s}, 85 \%, 40^{\circ} \mathrm{C}\right)$ and $\left(20 \mathrm{~s}, 85 \%, 25^{\circ} \mathrm{C}\right)$, respectively. 


\subsection{Aerosol mass spectrometer}

An Aerodyne quadrupole AMS was used during type 1 chamber studies and at the Jungfraujoch to provide online, quantitative measurements of the size distributed nonrefractory chemical composition of the submicron ambient aerosol at a high temporal resolution. An HR-ToF-AMS (DeCarlo et al., 2006) was deployed on the NCAR C-130 aircraft and type 2 chamber studies. More detailed descriptions of the AMS measurement principles and various calibrations (Canagaratna et al., 2007), its modes of operation (DeCarlo et al., 2006) and data processing and analysis are available elsewhere. The AMS provides the concentrations of inorganic ions, i.e. sulfate, nitrate, ammonium, and fragment ions associated with OA. In addition, the OA mass spectra provide further information on the aerosol. Several mass-to-charge ratios, specifically, $m / z 44, m / z 57$, and $m / z 60$ have been proposed as markers for oxygenated species, hydrocarbon-like (mostly urban combustion), and wood burning OA, respectively (Canagaratna et al., 2007; Alfarra et al., 2007). For the correlation analysis with particle hygroscopicity we use in the following the ratio of specific AMS OA mass fragments to total OA mass $\left(f_{x}\right.$, with $x$ being any integer $m / z$ ). As an example, for $m / z, 44$ this abundance is defined as

$f_{44}=\frac{m / z 44}{\text { Total organic mass }}$

\section{Theory and data analysis}

\subsection{The growth factor GF}

As shown in Eq. (1), the GF is associated with a certain RH. The water activity, $a_{\mathrm{w}}$, of a solution is defined as the equilibrium RH over a flat surface of this solution (i.e., in the absence of the Kelvin effect). The Köhler equation, $\mathrm{RH}=a_{\mathrm{w}} S_{\mathrm{k}}$, describes the equilibrium RH for a solution droplet, where $S_{\mathrm{k}}$ is the Kelvin factor defined as follows:

$S_{\mathrm{k}}=\exp \left(\frac{4 M_{\mathrm{w}} \sigma_{\mathrm{sol}}}{R T \rho_{\mathrm{w}} D_{\mathrm{p}}}\right)$

where $M_{\mathrm{w}}$ is the molar mass of water, $\rho_{\mathrm{w}}$ is the density of water, $\sigma_{\mathrm{sol}}$ is the surface tension of the solution, $R$ is the ideal gas constant, $T$ is the temperature and $D_{\mathrm{p}}$ is the wet diameter. In this study we used the surface tension of water for $\sigma_{\text {sol }}$. To compare GF values measured at different $a_{\mathrm{w}}$, we used the semi-empirical model described in Petters and Kreidenweis (2007), where GF and $a_{\mathrm{w}}$ of a particle are related as follows:

$\mathrm{GF}\left(a_{\mathrm{w}}\right)=\left(1+\kappa \frac{a_{\mathrm{w}}}{1-a_{\mathrm{w}}}\right)^{1 / 3}$

where the hygroscopicity parameter $\kappa$ captures all solute properties (such as the number of dissociated ions per molecule and the molal osmotic coefficient). Figure 1 shows

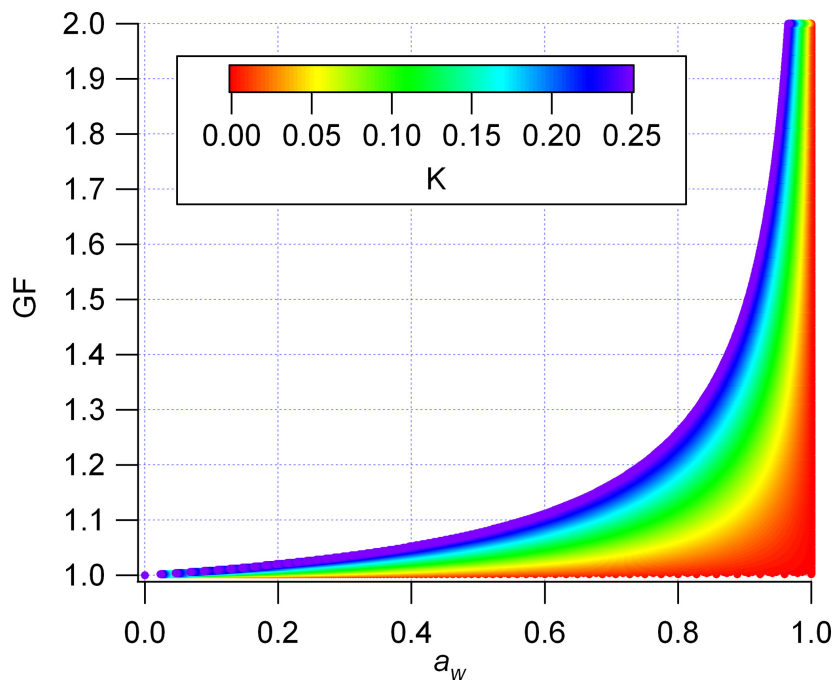

Fig. 1. Influence of the hygroscopicity parameter $\kappa$ on the relationship between the hygroscopic growth factor (GF) and the water activity $\left(a_{\mathrm{W}}\right)$.

the influence of $\kappa$ on the relationship between the growth factor (GF) and the water activity $\left(a_{\mathrm{w}}\right)$. More details about the theoretical background of the functionality of Eq. (4) are given in Kreidenweis et al. (2005) and Petters and Kreidenweis (2007).

\subsection{Retrieval of organic GF ( $\left.\mathbf{G F}_{\text {org }}\right)$ from an internally and externally mixed aerosol}

The hygroscopic growth factor of OA was directly measured in the pure SOA smog chamber experiments. However, the hygroscopicity of the organic fraction in ambient aerosol has to be deduced from the GF of the mixture $\left(\mathrm{GF}_{\text {mixed }}\right)$. The $\mathrm{GF}_{\text {mixed }}$ can be estimated from the growth factors of the individual components of the aerosol and their respective volume fractions, $\varepsilon$, with the ZSR relation (Meyer et al., 2009):

$\mathrm{GF}_{\text {mixed }}=\left(\sum_{i} \varepsilon_{i} \mathrm{GF}_{i}^{3}\right)^{1 / 3}$

with the summation performed over all compounds present in the particles. Solute-solute interactions are neglected in this model and volume additivity is also assumed. The concentrations of ammonium $\left(\mathrm{NH}_{4}^{+}\right)$, sulfate $\left(\mathrm{SO}_{4}^{2-}\right)$, nitrate $\left(\mathrm{NO}_{3}^{-}\right)$, and OA during these two field campaigns were obtained from the AMS measurements. In both campaigns, the aerosol was mostly neutralized with ammonium (DeCarlo et al., 2008; Cozic et al., 2008). The pairing of the inorganic ions, which is required for the ZSR relation, is unambiguous for aerosols neutralized by a single cation. However, occasionally the measured ammonium concentration was insufficient to fully neutralize the sulfate, thus indicating an acidic aerosol. In such cases the ion-pairing becomes ambiguous 
Table 2. GF and density used in the ZSR calculation (Bulk properties; Topping et al., 2005a).

\begin{tabular}{llc}
\hline Substance & $\begin{array}{l}\text { GF at } \\
a_{\mathrm{w}}=0.85\end{array}$ & $\begin{array}{c}\text { Densities } \\
{\left[\mathrm{kg} \mathrm{m}^{-3}\right]}\end{array}$ \\
\hline$\left(\mathrm{NH}_{4}\right)_{2} \mathrm{SO}_{4}$ & 1.56 & 1769 \\
$\mathrm{NH}_{4} \mathrm{HSO}_{4}$ & 1.62 & 1720 \\
$\mathrm{NH}_{4} \mathrm{NO}_{3}$ & 1.59 & 1780 \\
$\mathrm{H}_{2} \mathrm{SO}_{4}$ & 1.88 & 1830 \\
Organic & - & $1270^{\mathrm{a}}$ \\
\hline
\end{tabular}

a The density of organic was chosen to represent oxidized organics in aged atmospheric aerosol (Cross et al., 2007).

and therefore an adequate ion-pairing scheme must be applied. We excluded such periods and used the simplified ionpairing scheme presented by Gysel et al. (2007), which has a direct analytical solution and deviations of corresponding ZSR predictions from full thermodynamic models are minor for the relevant inorganic mixtures. Bulk growth factors of pure inorganic salts were obtained from the Aerosol Diameter Dependent Equilibrium Model (ADDEM; Topping et al., 2005a; Table 2). Densities used to convert mass fractions measured by the AMS into volume fractions required for the ZSR relation (Eq. 5) are also provided in Table 2. The growth factor of OA, the only unknown variable of Eq. (5), can then be calculated from the AMS (providing $\varepsilon$ ) and HTDMA (providing $\mathrm{GF}_{\text {mixed }}$ ) data.

When several growth factors were measured simultaneously (which occurred in Mexico data) due to external mixture of the aerosol, an average GF was then calculated using the following equation:

$\mathrm{GF}=\left(\sum_{i} n_{i} \mathrm{GF}_{i}^{3}\right)^{1 / 3}$

where $n_{i}$ is the number fraction of particles having the growth factor $\mathrm{GF}_{i}$. An important source of uncertainty for the retrieved $\mathrm{GF}_{\text {org }}$ is the organic density used. For ambient organic aerosol the densities reported in literature vary from 1200 to $1700 \mathrm{~kg} \mathrm{~m}^{-3}$ (Hallquist et al., 2009). Another source of uncertainty for the retrieved $\mathrm{GF}_{\text {org }}$ comes from the OA volume fraction $\left(\varepsilon_{\text {org }}\right)$. As shown in Fig. 2 , the $\mathrm{GF}_{\text {org }}$ uncertainty increases strongly as $\varepsilon_{\text {org }}$ decreases, since it is increasingly being determined as the difference of two large numbers in Eq. (5). The $\mathrm{GF}_{\text {org }}$ uncertainty also increases as the OA hygroscopicity decreases, since the size of the $\varepsilon_{\text {org }}$ $\mathrm{GF}_{\mathrm{org}}^{3}$ term in Eq. (5) is becoming smaller relative to the inorganic and total terms. Therefore, to keep the uncertainty lower, we restricted our data to $\varepsilon_{\text {org }}$ higher than $80 \%$ in the case of non hygroscopic organic $\left(\mathrm{GF}_{\mathrm{org}}(85 \%)=1\right)$ and $25 \%$ for very hygroscopic organic $\left(\mathrm{GF}_{\text {org }}(85 \%)=1.3\right)$. To keep a low $\varepsilon_{\text {org }}$ uncertainty, AMS data with a mass loading of OA

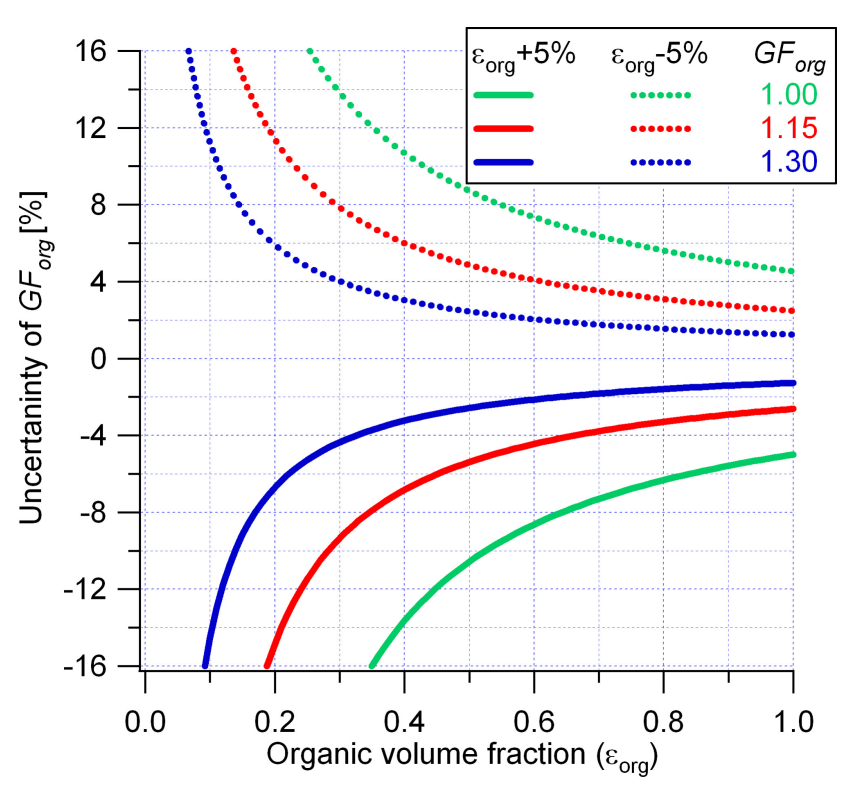

Fig. 2. Uncertainty of the retrieved $\mathrm{GF}_{\text {org }}$ due to AMS uncertainties. Errors calculated with $\varepsilon_{\mathrm{org}} \pm 5 \%\left(\varepsilon_{\mathrm{org}}-5 \%\right.$ for dashed line and $\varepsilon_{\text {org }}+5 \%$ for the filled lines) and an inorganic GF $=1.56$, assuming 3 different $\mathrm{GF}_{\text {org }}$ : $1,1.15$ and 1.3. With a higher $\mathrm{GF}_{\text {org }}$ or with a higher $\varepsilon_{\text {org }}$, the uncertainty of the calculated $\mathrm{GF}_{\text {org }}$ decreases. For example, for a non hygroscopic organic $\left(\mathrm{GF}_{\text {org }}=1\right)$, the retrieved $\mathrm{GF}_{\text {org }}$ is $1 \pm 0.06$ at $\varepsilon_{\text {org }}=0.8$ and $1 \pm 0.14$ at $\varepsilon_{\text {org }}=0.4$, whereas for a hygroscopic organic $\left(\mathrm{GF}_{\text {org }}=1.3\right)$ the retrieved $\mathrm{GF}_{\text {org }}$ is $1.3 \pm$ 0.02 at $\varepsilon_{\text {org }}=0.8$ and $1.3 \pm 0.04$ at $\varepsilon_{\text {org }}=0.4$.

less than $2 \mu \mathrm{g} \mathrm{m}^{-3}$ were excluded. The non-refractory materials (like black carbon and mineral dust) which are not measured by the AMS add additional uncertainty to the field data. These materials are typically non-hygroscopic and therefore the derived $\mathrm{GF}_{\text {org }}$ can be underestimated. From $\mathrm{GF}_{\text {org }}$, the hygroscopicity parameter for $\mathrm{OA}, \kappa_{\mathrm{org}}$ was determined using Eq. (4).

\subsection{Statistical method for correlation analysis of the smog chamber data}

The forward screening method is used to evaluate the correlation of AMS data with $\kappa$ for the smog chamber data.

A thorough description of this method is given in Wilks (2006). Briefly, in a first step, the linear correlation coefficient of $\kappa$ with each $f_{x}$ is calculated and the $f_{x}$ yielding the highest value is kept for the next step. In the second step, a tri-linear regression analysis with $\kappa$ and the $f_{x}$ selected from the first step and with each remaining $f_{x}$ is performed (i.e. $\kappa=a \times f_{1 \text { st step }}+b \times f_{x}+c$ ). The $f_{x}$ yielding the best prediction of $\kappa$ is then kept with the previous one for the next step. The method is stopped when there is no more significant improvement of $R^{2}\left(\Delta R^{2}<0.05\right)$ when adding another $f_{x}$. 


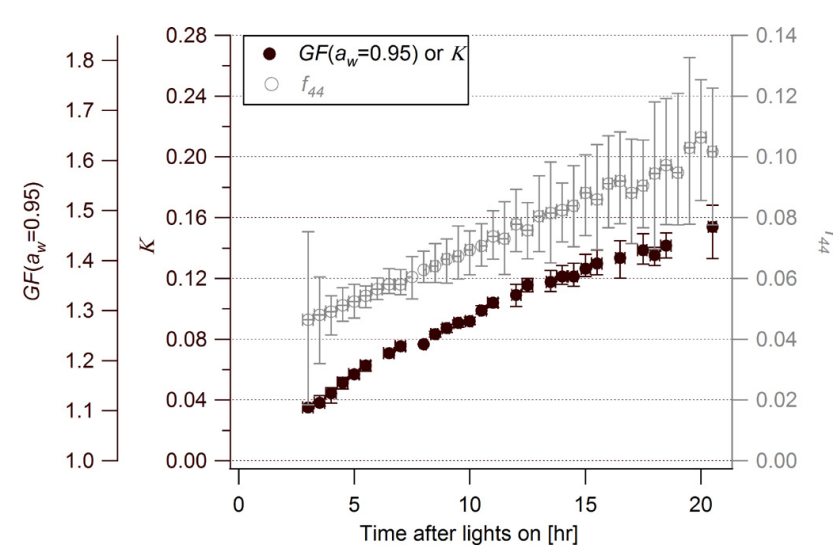

Fig. 3. Temporal evolution of the GF at $a_{\mathrm{w}}=0.95$ and the corresponding $\kappa_{\text {org }}$ value (closed symbol) and $f_{44}$ (open symbol) for SOA formed from $150 \mathrm{ppb} \mathrm{TMB}$ and $75 \mathrm{ppb} \mathrm{NO}_{2}$ (Experiment 1 from Table 1). Each data point represents a 30-minute average.

\section{Results and discussion}

\subsection{Smog chamber data}

In the smog chamber experiments, the SOA GF was measured with HTDMA1. The dry diameter was adjusted according to the number mode of the aerosol during its growth. Figure 3 shows the typical time trends during a photooxidation experiment with TMB (experiment 1 in Table 1). Both the hygroscopicity of the SOA (expressed as $\kappa_{\text {org }}$ and GF $\left.\left(a_{\mathrm{w}}=0.95\right)\right)$ and $f_{44}$ increase during the course of the experiment, i.e. with increasing integrated oxidant exposure. A similar trend of $\kappa_{\text {org }}$ and $f_{44}$ was measured for SOA formed from $\alpha$-pinene (see Fig. 1 in Duplissy et al., (2008)) as well as from isoprene.

For each chamber experiment $f_{44}$ showed the highest linear correlation of any $f_{x}$ with $\kappa_{\text {org }}$, (with $R^{2}>0.92$ and significance $\alpha=0$ excluding experiment 5 where $\kappa_{\text {org }}$ and $f_{44}$ were not measured simultaneously, see Table 1). By comparison, no other $f_{x}$ was found to correlate with $\kappa_{\text {org }}$ with $R^{2}>0.64$. Figure 4 shows the correlation coefficient of the estimated $\kappa_{\text {org }}$ versus the different $f_{x}$ for the three different precursors. Both correlation $(R>0)$ and anti-correlation $(R<0)$ are observed. Specific $f_{x}$ (like for example $f_{55}$ ) can either correlate or anti-correlate with $\kappa_{\text {org }}$ depending on the precursor. In addition, the $R$ between $\kappa$ and each $f_{x}$ for all smog chamber data (all precursors together) with significance lower than 0.05 is shown in Fig. 5. With all experiments combined together, a correlation analysis of the calculated $\kappa_{\text {org }}$ and $f_{x}$ has been performed using the screening regression method and using $f_{30}, f_{44}$ and $f_{46}$ (as suggested by Fig. 5) as three different initial first steps. In doing so, these three analyses suggest that $f_{30}, f_{44}, f_{46}$ and $f_{55}$ are the four parameters which should be used to make a multiple linear regression with $\kappa_{\text {org }}$ (see Fig. 6). It should be noted that $\mathrm{m} / \mathrm{z}, 30$ and 46 for laboratory data are assumed to be due

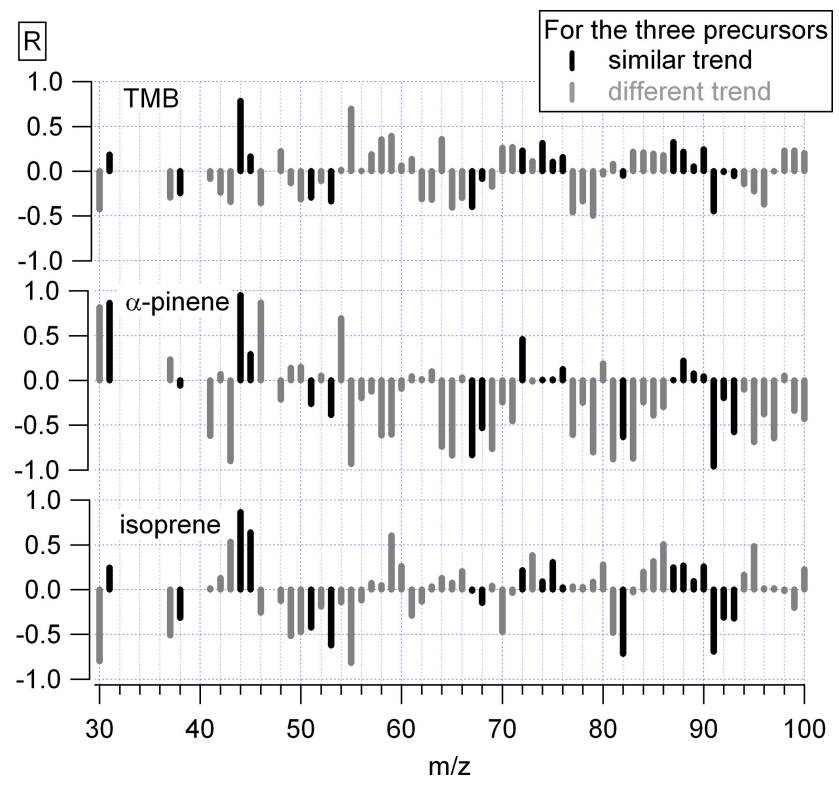

Fig. 4. Correlation analysis of the estimated $\kappa_{\text {org }}$ with $f_{x}$ (for $m / z, 30$ to $m / z, 100$ ) for the photooxidation experiments with different precursors. Black bars indicate that the $m / z$ had a similar sign for $R$ for all precursors studied here. In contrast grey bars indicate that for one precursor $R$ has a different sign compared to the other precursor for a same fragment.

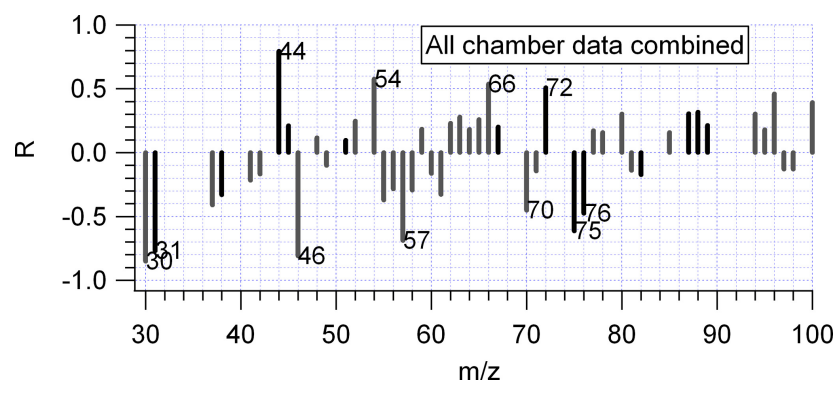

Fig. 5. Correlation coefficient between $\kappa_{\text {org }}$ and each $f_{x}$ for the complete smog chamber data set. Black bars indicate that the $\mathrm{m} / \mathrm{z}$ had a similar sign for $R$ for all precursors studied here. In contrast grey bars indicate that for one precursor $R$ has a different sign compared to the other precursor for the same fragment. Data with a significance $\alpha>0.05$ are not shown.

to $\mathrm{OA}$, even if the signals arise also from $\mathrm{NO}^{+}$and $\mathrm{NO}_{2}^{+}$. This assumption is not valid for ambient data where $\mathrm{m} / \mathrm{z} 30$ and 46 are typically dominated by inorganic ammonium nitrate (Zhang et al., 2007b), and as such these signals are not dominated by variations in the composition of the OA.

From a chemical point of view $f_{43}\left(f_{43}>15 \%\right)$ could also have a correlation with GF from SOA generated in smog chambers and could also be considered as an additional parameter to improve the correlation. However, as shown in Fig. 4, $f_{43}$ and GF can be either correlated or anti-correlated depending of the precursor. For the full data set, adding 


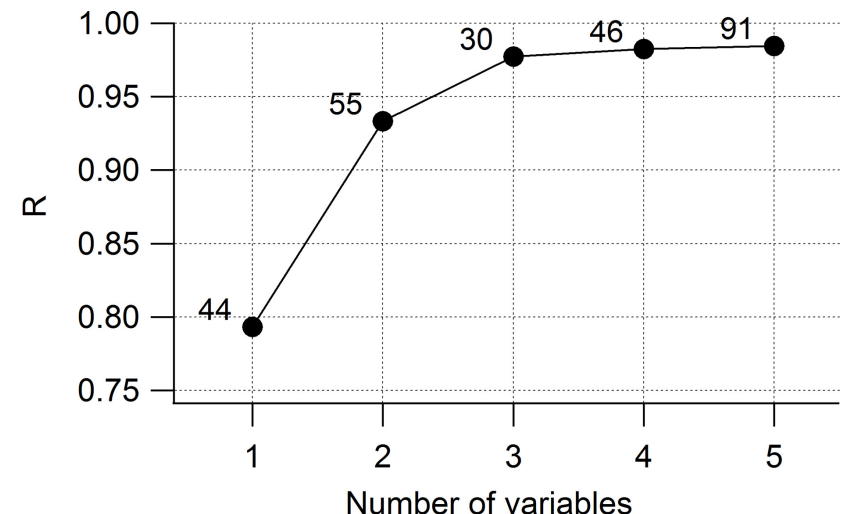

Fig. 6. Result from the screening multiple linear regression of all smog chamber data sets, with $f_{44}$ as the first input variable. Choosing $f_{30}$ or $f_{46}$ or $f_{55}$ as first input variable for the screening regression results in the same four $f_{x}$ being selected by the procedure (not shown).

$f_{43}$ to $f_{44}$ improves the correlation with $\kappa_{\text {org }}\left(R^{2}\right.$ increases from 0.8 to 0.9 ). However, ambient aerosol contains not only SOA but also a substantial contribution from primary OA (POA), and both $m / z 43$ and $m / z 55$ are prominent in reduced POA mass spectra (typically from the ions $\mathrm{C}_{3} \mathrm{H}_{7}^{+}$and $\mathrm{C}_{4} \mathrm{H}_{7}^{+}$, respectively) (Lanz et al., 2007; Canagaratna et al., 2004; Zhang et al., 2005), besides being components of the SOA mass spectra (typically the ions $\mathrm{C}_{2} \mathrm{H}_{3} \mathrm{O}^{+}$and $\mathrm{C}_{3} \mathrm{H}_{3} \mathrm{O}^{+}$, respectively) (Alfarra et al., 2006). Due to the different sources of $\mathrm{m} / \mathrm{z} 43$ and $\mathrm{m} / \mathrm{z} 55$, and the differing hygroscopic properties of OA associated with these sources, ambient datasets are less suitable than chamber data for fitting $\kappa_{\text {org }}$ with these $\mathrm{m} / z$. $\mathrm{m} / \mathrm{z} 44$ is mainly associated with the $\mathrm{CO}_{2}^{+}$ion fragment, and data from the HR-ToF-AMS indicate that there is only a minor contribution from $\mathrm{C}_{2} \mathrm{H}_{4} \mathrm{O}^{+}$in SOA as well as in ambient air (Mohr et al., 2009). Therefore, due to these interferences on ambient OA measurements, only $f_{44}$ can be used here in both lab and field data as a proxy for $\kappa_{\text {org }}$.

The correlation between $\kappa_{\text {org }}$ and $f_{44}$ is shown in Fig. 7 and is also found in field experiments (see below). It is likely explained by the fact that $m / z 44$ is a major fragment of highly oxidized organic species such as organic di-acids, poly-acids, oxo-acids, hydroxy-acids, and acyl peroxides (Aiken et al., 2007; Aiken et al., 2008), and is also highly correlated with the bulk atomic O/C ratio of the OA (Aiken et al., 2007; Aiken et al., 2008), which is given as a secondary x-axis in Fig. 7. These functional groups are expected to have a rather high hygroscopicity. Plotting $f_{44}$ versus $\kappa_{\text {org }}$ the data lies on the same line for $\alpha$-pinene and isoprene SOA, while data from TMB SOA are shifted to higher $\kappa_{\text {org }}$ for the same $f_{44}$ (Fig. 7). This result may be due to the fact that in SOA from TMB photooxidation, the acids present in the aerosol are mainly mono-acids ( $>90 \%$ ), while the acids found in the SOA from $\alpha$-pinene or isoprene photooxidation are approximately half mono- and half di-acids (Gäggeler, 2008).

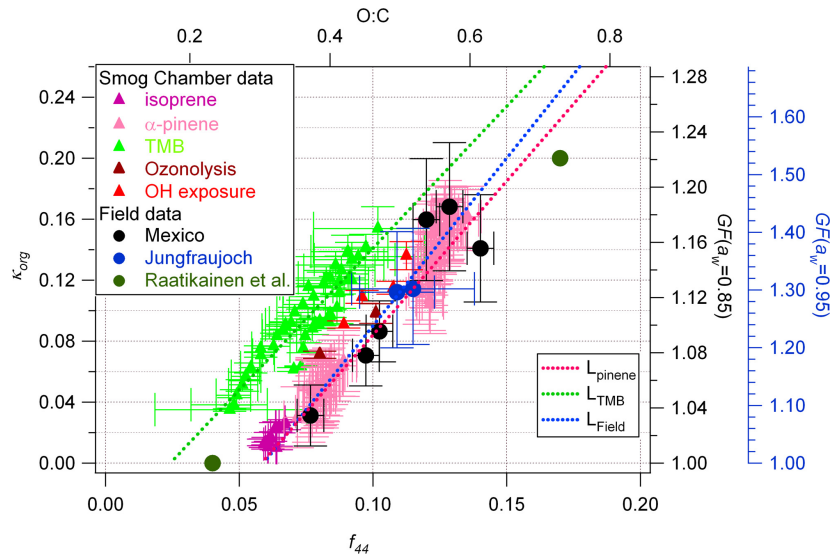

Fig. 7. Relationship between $f_{44}$ and $\kappa_{\text {org }}$ for field data (Jungfraujoch and Mexico City), smog chamber data (SOA formed from traditional photooxidation of isoprene, $\alpha$-pinene and 1,3,5trimethylbenzene, from the ozonolysis of $\alpha$-pinene and subsequent OH exposure. Data of Raatikainen et al. (2010) are also shown. Linear regression fits are shown for TMB $\left(L_{\mathrm{TMB}}\right)$, isoprene/ $\alpha$-pinene ( $\left.L_{\text {pinene }}\right)$ and field data $\left(L_{\text {field }}\right)$.

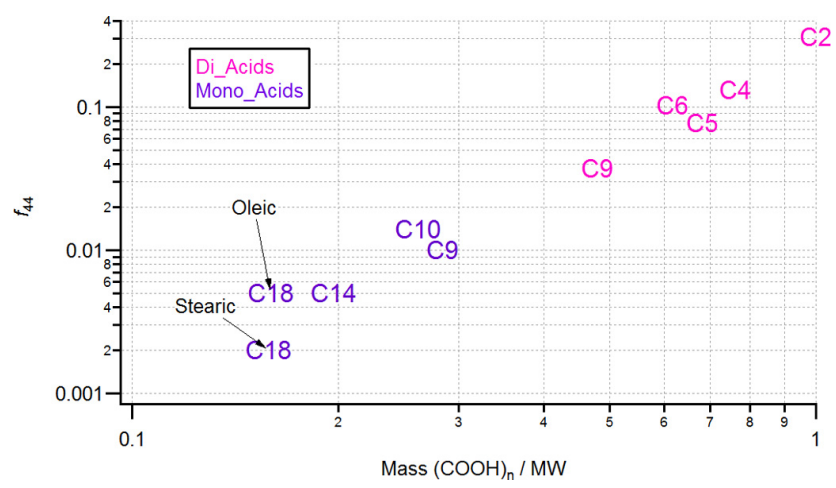

Fig. 8. The fractional contribution of $m / z 44\left(f_{44}\right)$ for mono- and di-carboxylic acids versus the ratio of the mass of carboxylic acid groups to the molecular mass of the individual acids. This figure normalizes the mass of the acid groups to the molecular weight and compares it to $f_{44}$ in the mass spectrum for each acid. It shows a tendency for di-acids to produce more $\mathrm{m} / \mathrm{z}, 44$ per $\mathrm{COOH}$ group than mono-acids.

Alfarra (2004) using pure standards showed that the signal response of $m / z 44$ per organic acid group is lower for monoacids than for diacids (Fig. 8). This is consistent with the offset observed here in Fig. 7 between TMB and biogenic precursors.

\subsection{Ambient data}

The aerosol at the Jungfraujoch shows an annual cycle with highest mass concentrations in July to August and minimum concentrations in January to February. The OA fraction is higher during the summer season (e.g. Cozic et al., 2008). 
Periods with OA concentrations higher than $2 \mu \mathrm{g} \mathrm{m}^{-3}$ and a volume fraction of OA higher than $80 \%$ were only found during the summer CLACE3 campaign, and therefore only data from this period are shown. The restriction of the data set to these mass loadings and volume fractions is based on the uncertainties to calculate $\mathrm{GF}_{\text {org }}$ as described above. 3-h averages were calculated as a trade-off between counting statistics and time resolution. HTDMA2 measured the hygroscopic properties of particles with $D_{0}=100 \mathrm{~nm}$. The AMS composition data were integrated over a narrow size range from 88-196 nm vacuum aerodynamic diameter, which corresponds to a volume-equivalent diameter of $100 \mathrm{~nm}$ (56$125 \mathrm{~nm}$ ) as described in Sjogren et al. (2008) and using the framework detailed in DeCarlo et al. (2004).

A large fraction of the OA in Mexico City is oxidized, with an oxygen-to-carbon atomic ratio $(\mathrm{O} / \mathrm{C})$ that increases with distance from the city approaching a ratio of 0.9 away from the basin indicating photochemical ageing of OA (DeCarlo et al., 2008; Aiken et al., 2008). The NCAR-NSF C130 performed 12 research flights (RFs) during the MILAGRO campaign. Measurements in the aircraft constrain the black carbon (BC) and dust fractions to be small, of the order of a few percent of the total submicron mass (DeCarlo et al., 2008). Data reported here are from RFs 3 and 12 (10 and 29 March 2006, respectively) and both had city and regional components in their flight tracks (DeCarlo et al., 2008, 2010). The OA contained important influences from urban POA, anthropogenic SOA, and biomass burning POA and SOA (DeCarlo et al., 2010). The aerosol mass distribution was dominated by larger particles $\left(D_{\mathrm{va}}>200 \mathrm{~nm}\right)$. Therefore, all AMS data were integrated (no size distinction) and GFs only from larger particles $\left(D_{\mathrm{m}}=200 \mathrm{~nm}\right.$ and $\left.300 \mathrm{~nm}\right)$ measured by HTDMA3 were analyzed assuming the same bulk chemical composition. A limitation of aircraft measurements is that air masses can change rapidly, often within an HTDMA measurement cycle. Therefore care was taken to include only data where the aerosol mass and composition were stable during an HTDMA3 scan. This was determined using the AMS data (12 second resolution), and data with a variation of either the $f_{44}$ or the organic to inorganic ratio higher than $10 \%$ during the hygroscopicity measurement were excluded.

For each period with a valid calculation of $\mathrm{GF}_{\text {org }}$ and corresponding $\kappa_{\text {org }}, f_{44}$ was extracted from the AMS measurements. Ambient data are also presented in Figure 7. It is obvious from this figure that $\kappa_{\text {org }}$ and $f_{44}$ show a strong and consistent dependence and that $\kappa_{\text {org }}$ may be approximated from $f_{44}$ according to the equation

$\kappa_{\mathrm{org}}=a \times f_{44}+b$

The parameters $a, b$ are given in Table 3 for this relationship for TMB, $\alpha$-pinene and isoprene as well as the ambient data separately. Smog chamber data from both biogenic precursors and field data at both locations show a consistent relationship between $f_{44}$ and $\kappa_{\text {org }}$ within the uncertainties. The
Table 3. Correlation parameters of Eq. (7) for the different aerosols.

\begin{tabular}{lcc}
\hline Variable & $a$ & $b$ \\
\hline TMB & $1.86 \pm 0.02$ & $-0.045 \pm 0.01$ \\
$\alpha$-pinene, isoprene & $2.02 \pm 0.04$ & $-0.118 \pm 0.005$ \\
Jungfraujoch/Mexico & $2.2 \pm 0.4$ & $-0.13 \pm 0.05$ \\
\hline
\end{tabular}

slope for TMB is similar to the other results but there is an offset as explained above. Recently Raatikainen et al. (2010) reported growth factors of 1.0 and 1.29 at $88 \% \mathrm{RH}$ for $50-\mathrm{nm}$ particles (corresponding to $\kappa_{\text {org }}$ of 0 and 0.2 , respectively) at $f_{44}$ of 0.04 and 0.17 respectively. Both values are in good agreement with our data and also support our observation that OA with $f_{44}<0.06$ seems to be effectively non-hygroscopic.

In this study we investigate the relationship between the oxidation level of the SOA and its hygroscopic growth factor at subsaturated RH. Chang et al. (2010) reported a similar relationship for $\kappa_{\text {org }}\left(\kappa_{\text {org }}=(0.29 \pm 0.05) \times(\mathrm{O} / \mathrm{C})\right) \mathrm{de}-$ rived from ambient cloud condensation nuclei $(\mathrm{CCN})$ measurements at supersaturated RH. This slope differs from our results, which can likely be attributed to decreased importance of non-ideal interactions in dilute solutions at the point of CCN activation (Petters et al., 2009). Several laboratory studies reported differences between HTDMA- and CCNCderived $\kappa_{\text {org }}$ of SOA (e.g. Prenni et al., 2007; Wex et al., 2009; Juranyi et al., 2009, Good et al., 2010). Massoli et al. (2010) showed for different proxies of anthropogenic and biogenic SOA that the relationship between $\mathrm{O} / \mathrm{C}$ ratio and $\mathrm{CCN}$-derived kappa value is non-linear.

\section{Conclusions}

A simplifying approximation, such as the one proposed here, could introduce an important improvement in the parameterization of hygroscopicity in atmospheric models, since $f_{44}$ is significantly correlated with the photochemical age of the air mass (DeCarlo et al., 2008; Aiken et al., 2008) and the database for such AMS measurements is constantly being expanded around the world (Jimenez et al., 2009). We recommend testing the general applicability of Eq. (7) with more ambient and chamber measurements, including a variety of different POA sources (e.g. diesel exhaust and biomass burning OA, fresh and aged), and in both the sub- and supersaturated regimes. The ability of the HR-ToF-AMS to distinguish individual ions at the same nominal $\mathrm{m} / \mathrm{z}$ could potentially eliminate some of the interferences mentioned above for other nominal $\mathrm{m} / \mathrm{z}$ and yield other ions that can be used to improve the $\kappa_{\text {org }}$ calculation. If generally applicable, this relationship would substantially improve our ability to describe the evolution of hygroscopicity at subsaturated RH in a variety of atmospheric models. 
Acknowledgements. This work was supported by the Swiss National Science Foundation as well as by the EC projects EUROCHAMP, POLYSOA, and EUCAARI. JLJ was supported by NOAA grant NA08OAR4310565. PFD is grateful for funding from NSF IRFP (0701013). J. Duplissy was supported from the EC's 7th Framework Programme under grant agreement number 215072 (Marie Curie Initial Training Network "CLOUD-ITN").

Edited by: M. Petters

\section{References}

Aiken, A. C., DeCarlo, P. F., and Jimenez, J. L.: Elemental analysis of organic species with electron ionization highresolution mass spectrometry, Anal. Chem., 79, 8350-8358, doi:10.1021/ac071150w, 2007.

Aiken, A. C., Decarlo, P. F., Kroll, J. H., Worsnop, D. R., Huffman, J. A., Docherty, K. S., Ulbrich, I. M., Mohr, C., Kimmel, J. R., Sueper, D., Sun, Y., Zhang, Q., Trimborn, A., Northway, M., Ziemann, P. J., Canagaratna, M. R., Onasch, T. B., Alfarra, M. R., Prévôt, A. S. H., Dommen, J., Duplissy, J., Metzger, A., Baltensperger, U., and Jimenez, J. L.: O/C and OM/OC ratios of primary, secondary, and ambient organic aerosols with highresolution time-of-flight aerosol mass spectrometry, Environ. Sci. Technol., 42, 4478-4485, doi:10.1021/es703009q, 2008.

Alfarra, M. R.: Insights into atmospheric organic aerosols using an aerosol mass spectrometer, $\mathrm{PhD}$ thesis, Chemical Enginering Departement, University of Manchester Institute of Science and Technology, Manchester, UK, 2004.

Alfarra, M. R., Paulsen, D., Gysel, M., Garforth, A. A., Dommen, J., Prévôt, A. S. H., Worsnop, D. R., Baltensperger, U., and Coe, H.: A mass spectrometric study of secondary organic aerosols formed from the photooxidation of anthropogenic and biogenic precursors in a reaction chamber, Atmos. Chem. Phys., 6, 52795293, doi:10.5194/acp-6-5279-2006, 2006.

Alfarra, M. R., Prévôt, A. S. H., Szidat, S., Sandradewi, J., Weimer, S., Lanz, V. A., Schreiber, D., Mohr, M., and Baltensperger, U.: Identification of the mass spectral signature of organic aerosols from wood burning emissions, Environ. Sci. Technol., 41, 57705777, doi:10.1021/es062289b, 2007.

Canagaratna, M. R., Jayne, J. T., Ghertner, D. A., Herndon, S., Shi, Q., Jimenez, J. L., Silva, P. J., Williams, P., Lanni, T., Drewnick, F., Demerjian, K. L., Kolb, C. E., and Worsnop, D. R.: Chase studies of particulate emissions from in-use new york city vehicles, Aerosol Sci. Tech., 38, 555-573, doi:10.1080/02786820490465504, 2004.

Canagaratna, M. R., Jayne, J. T., Jimenez, J. L., Allan, J. D., Alfarra, M. R., Zhang, Q., Onasch, T. B., Drewnick, F., Coe, H., Middlebrook, A., Delia, A., Williams, L. R., Trimborn, A. M., Northway, M. J., DeCarlo, P. F., Kolb, C. E., Davidovits, P., and Worsnop, D. R.: Chemical and microphysical characterization of ambient aerosols with the Aerodyne aerosol mass spectrometer, Mass Spectrom. Rev., 26, 185-222, doi:10.1002/mas.20115, 2007.

Chang, R. Y.-W., Slowik, J. G., Shantz, N. C., Vlasenko, A., Liggio, J., Sjostedt, S. J., Leaitch, W. R., and Abbatt, J. P. D.: The hygroscopicity parameter $\kappa$ of ambient organic aerosol at a field site subject to biogenic and anthropogenic influences: relation- ship to degree of aerosol oxidation, Atmos. Chem. Phys., 10, 5047-5064, doi:10.5194/acp-10-5047-2010, 2010.

Choi, M. Y., and Chan, C. K.: The effects of organic species on the hygroscopic behaviors of inorganic aerosols, Environ. Sci. Technol., 36, 2422-2428, doi:10.1021/es0113293, 2002a.

Choi, M. Y., and Chan, C. K.: Continuous measurements of the water activities of aqueous droplets of water-soluble organic compounds, J. Phys. Chem., A106, 4566-4572, doi:10.1021/jp013875o, 2002b.

Clegg, S. L., Seinfeld, J. H., and Brimblecombe, P.: Thermodynamic modelling of aqueous aerosols containing electrolytes and dissolved organic compounds, J. Aerosol Sci., 32, 713-738, 2001.

Collaud Coen, M., Weingartner, E., Nyeki, S., Cozic, J., Henning, S., Verheggen, B., Gehrig, R., and Baltensperger, U.: Long-term trend analysis of aerosol variables at the high alpine site Jungfraujoch, J. Geophys. Res., 112, D13213, doi:10.1029/2006JD007995, 2007.

Cozic, J., Verheggen, B., Weingartner, E., Crosier, J., Bower, K. N., Flynn, M., Coe, H., Henning, S., Steinbacher, M., Henne, S., Collaud Coen, M., Petzold, A., and Baltensperger, U.: Chemical composition of free tropospheric aerosol for PM1 and coarse mode at the high alpine site Jungfraujoch, Atmos. Chem. Phys., 8, 407-423, doi:10.5194/acp-8-407-2008, 2008.

Cross, E. S., Slowik, J. G., Davidovits, P., Allan, J. D., Worsnop, D. R., Jayne, J. T., Lewis, D. K., Canagaratna, M., and Onasch, T. B.: Laboratory and ambient particle density determinations using light scattering in conjunction with aerosol mass spectrometry, Aerosol Sci. Technol., 41, 343-359, doi:10.1080/02786820701199736, 2007.

Cruz, C. N. and Pandis, S. N.: Deliquescence and hygroscopic growth of mixed inorganic-organic atmospheric aerosol, Environ. Sci. Technol., 34, 4313-4319, doi:10.1021/es9907109, 2000.

Cubison, M. J., Alfarra, M. R., Allan, J., Bower, K. N., Coe, H., McFiggans, G. B., Whitehead, J. D., Williams, P. I., Zhang, Q., Jimenez, J. L., Hopkins, J., and Lee, J.: The characterisation of pollution aerosol in a changing photochemical environment, Atmos. Chem. Phys., 6, 5573-5588, doi:10.5194/acp-6-5573-2006, 2006.

DeCarlo, P. F., Slowik, J. G., Worsnop, D. R., Davidovits, P., and Jimenez, J. L.: Particle morphology and density characterization by combined mobility and aerodynamic diameter measurements, Part 1: Theory, Aerosol Sci. Technol., 38, 1185-1205, doi:10.1080/027868290903907, 2004.

DeCarlo, P. F., Kimmel, J. R., Trimborn, A., Northway, M. J., Jayne, J. T., Aiken, A. C., Gonin, M., Fuhrer, K., Horvath, T., Docherty, K. S., Worsnop, D. R., and Jimenez, J. L.: Field-deployable, high-resolution, time-of-flight aerosol mass spectrometer, Anal. Chem., 78, 8281-8289, doi:10.1021/ac061249n, 2006.

DeCarlo, P. F., Dunlea, E. J., Kimmel, J. R., Aiken, A. C., Sueper, D., Crounse, J., Wennberg, P. O., Emmons, L., Shinozuka, Y., Clarke, A., Zhou, J., Tomlinson, J., Collins, D. R., Knapp, D., Weinheimer, A. J., Montzka, D. D., Campos, T., and Jimenez, J. L.: Fast airborne aerosol size and chemistry measurements above Mexico City and Central Mexico during the MILAGRO campaign, Atmos. Chem. Phys., 8, 4027-4048, doi:10.5194/acp8-4027-2008, 2008.

DeCarlo, P. F., Ulbrich, I. M., Crounse, J., de Foy, B., Dunlea, 
E. J., Aiken, A. C., Knapp, D., Weinheimer, A. J., Campos, T., Wennberg, P. O., and Jimenez, J. L.: Investigation of the sources and processing of organic aerosol over the Central Mexican Plateau from aircraft measurements during MILAGRO, Atmos. Chem. Phys., 10, 5257-5280, doi:10.5194/acp-10-52572010, 2010.

Duplissy, J., Gysel, M., Alfarra, M. R., Dommen, J., Metzger, A., Prévôt, A. S. H., Weingartner, E., Laaksonen, A., Raatikainen, T., Good, N., Turner, S. F., McFiggans, G., and Baltensperger, U.: Cloud forming potential of secondary organic aerosol under near atmospheric conditions, Geophys. Res. Lett., 35, L03818, doi:10.1029/2007GL031075, 2008.

Duplissy, J., Gysel, M., Sjogren, S., Meyer, N., Good, N., Kammermann, L., Michaud, V., Weigel, R., Martins dos Santos, S., Gruening, C., Villani, P., Laj, P., Sellegri, K., Metzger, A., McFiggans, G. B., Wehrle, G., Richter, R., Dommen, J., Ristovski, Z., Baltensperger, U., and Weingartner, E.: Intercomparison study of six HTDMAs: results and recommendations, Atmos. Meas. Tech., 2, 363-378, doi:10.5194/amt-2-363-2009, 2009.

Fredenslund, A., Jones, R. L., and Prausnitz, J. M.: Groupcontribution estimation of activity-coefficients in nonideal liquid-mixtures, Aiche J., 21, 1086-1099, 1975.

Gäggeler, K.: Small molecular weight organic acids in the gas and aerosol phase, PhD thesis ETH-18042, Zurich, 2008.

Gasparini, R., Li, R. J., and Collins, D. R.: Integration of size distributions and size-resolved hygroscopicity measured during the Houston supersite for compositional categorization of the aerosol, Atmos. Environ., 38, 3285-3303, doi:10.1016/j.atmosenv.2004.03.019, 2004.

Goldstein, A. H. and Galbally, I. E.: Known and unexplored organic constituents in the earth's atmosphere, Environ. Sci. Technol., 41, 1514-1521, 2007.

Good, N., Topping, D. O., Duplissy, J., Gysel, M., Meyer, N. K., Metzger, A., Turner, S. F., Baltensperger, U., Ristovski, Z., Weingartner, E., Coe, H., and McFiggans, G.: Widening the gap between measurement and modelling of secondary organic aerosol properties?, Atmos. Chem. Phys., 10, 2577-2593, doi:10.5194/acp-10-2577-2010, 2010.

Gysel, M., Crosier, J., Topping, D. O., Whitehead, J. D., Bower, K. N., Cubison, M. J., Williams, P. I., Flynn, M. J., McFiggans, G. B., and Coe, H.: Closure study between chemical composition and hygroscopic growth of aerosol particles during TORCH2, Atmos. Chem. Phys., 7, 6131-6144, doi:10.5194/acp-7-61312007, 2007.

Hallquist, M., Wenger, J. C., Baltensperger, U., Rudich, Y., Simpson, D., Claeys, M., Dommen, J., Donahue, N. M., George, C., Goldstein, A. H., Hamilton, J. F., Herrmann, H., Hoffmann, T., Iinuma, Y., Jang, M., Jenkin, M. E., Jimenez, J. L., Kiendler-Scharr, A., Maenhaut, W., McFiggans, G., Mentel, Th. F., Monod, A., Prévôt, A. S. H., Seinfeld, J. H., Surratt, J. D., Szmigielski, R., and Wildt, J.: The formation, properties and impact of secondary organic aerosol: current and emerging issues, Atmos. Chem. Phys., 9, 5155-5236, doi:10.5194/acp-95155-2009, 2009.

Hämeri, K., Charlson, R., and Hansson, H. C.: Hygroscopic properties of mixed ammonium sulfate and carboxylic acids particles, Aiche J., 48, 1309-1316, 2002.

Hegg, D. A., Gao, S., Hoppel, W., Frick, G., Caffrey, P., Leaitch, W. R., Shantz, N., Ambrusko, J., and Albrechcinski, T.: Laboratory studies of the efficiency of selected organic aerosols as CCN, Atmos. Res., 155-166, 2001.

Jimenez, J. L., Canagaratna, M. R., Donahue, N. M., Prévôt, A. S. H., Zhang, Q., Kroll, J. H., Decarlo, P. F., Allan, J. D., Coe, H., Ng, N. L., Aiken, A. C., Docherty, K. S., Ulbrich, I. M., Grieshop, A. P., Robinson, A. L., Duplissy, J., Smith, J. D., Wilson, K. R., Lanz, V. A., Hueglin, C., Sun, Y. L., Tian, J., Laaksonen, A., Raatikainen, T., Rautiainen, J., Vaattovaara, P., Ehn, M., Kulmala, M., Tomlinson, J. M., Collins, D. R., Cubison, M. J., Dunlea, E. J., Huffman, J. A., Onasch, T. B., Alfarra, M. R., Williams, P. I., Bower, K., Kondo, Y., Schneider, J., Drewnick, F., Borrmann, S., Weimer, S., Demerjian, K., Salcedo, D., Cottrell, L., Griffin, R., Takami, A., Miyoshi, T., Hatakeyama, S., Shimono, A., Sun, J. Y., Zhang, Y. M., Dzepina, K., Kimmel, J. R., Sueper, D., Jayne, J. T., Herndon, S. C., Trimborn, A. M., Williams, L. R., Wood, E. C., Middlebrook, A. M., Kolb, C. E., Baltensperger, U., and Worsnop, D. R.: Evolution of organic aerosols in the atmosphere, Science, 326, 1525-1529, doi:10.1126/science.1180353, 2009.

Jurányi, Z., Gysel, M., Duplissy, J., Weingartner, E., Tritscher, T., Dommen, J., Henning, S., Ziese, M., Kiselev, A., Stratmann, F., George, I., and Baltensperger, U.: Influence of gasto-particle partitioning on the hygroscopic and droplet activation behaviour of $\alpha$-pinene secondary organic aerosol, Phys. Chem. Chem. Phys., 11, 8091-8097, doi:10.1039/b904162a, 2009.

Kreidenweis, S. M., Koehler, K., DeMott, P. J., Prenni, A. J., Carrico, C., and Ervens, B.: Water activity and activation diameters from hygroscopicity data - Part I: Theory and application to inorganic salts, Atmos. Chem. Phys., 5, 1357-1370, doi:10.5194/acp-5-1357-2005, 2005.

Lanz, V. A., Alfarra, M. R., Baltensperger, U., Buchmann, B., Hueglin, C., and Prévôt, A. S. H.: Source apportionment of submicron organic aerosols at an urban site by factor analytical modelling of aerosol mass spectra, Atmos. Chem. Phys., 7, 1503-1522, doi:10.5194/acp-7-1503-2007, 2007.

Liu, B. Y. H., Pui, D. Y. H., Whitby, K. T., Kittelson, D. B., Kousaka, Y., and McKenzie, R. L.: Aerosol mobility chromatograph - new detector for sulfuric-acid aerosols, Atmos. Environ., 12, 99-104, 1978.

Massoli, P., Lambe, A. T., Ahern, A. T., Williams, L. R., Ehn, M., Mikkilä, J., Canagaratna, M. R., Brune, W. H., Onasch, T. B., Jayne, J. T., Petäjä, T., Kulmala, M., Laaksonen, A., Kolb, C. E., Davidovits, P., and Worsnop, D. R.: Relationship between aerosol oxidation level and hygroscopic properties of laboratory generated secondary organic aerosol (SOA) particles, Geophys. Res. Lett., 37, L24801, doi:10.1029/2010GL045258, 2010.

Meyer, N. K., Duplissy, J., Gysel, M., Metzger, A., Dommen, J., Weingartner, E., Alfarra, M. R., Prévôt, A. S. H., Fletcher, C., Good, N., McFiggans, G., Jonsson, Å. M., Hallquist, M., Baltensperger, U., and Ristovski, Z. D.: Analysis of the hygroscopic and volatile properties of ammonium sulphate seeded and unseeded SOA particles, Atmos. Chem. Phys., 9, 721-732, doi:10.5194/acp-9-721-2009, 2009.

Mohr, C., Huffman, J. A., Cubison, M. J., Aiken, A. C., Docherty, K. S., Kimmel, J. R., Ulbricht, I. M., Hannigan, M., and Jimenez, J. L.: Characterization of primary organic aerosol emissions from meat cooking, trash burning, and motor vehicles with highresolution aerosol mass spectrometry and comparison with ambient and chamber observations, Environ. Sci. Technol., 43, 2443- 
2449, doi:10.1021/es8011518, 2009.

Paulsen, D., Dommen, J., Kalberer, M., Prévôt, A. S. H., Richter, R., Sax, M., Steinbacher, M., Weingartner, E., and Baltensperger, U.: Secondary organic aerosol formation by irradiation of 1,3,5trimethylbenzene- $\mathrm{NO}_{\mathrm{x}}-\mathrm{H}_{2} \mathrm{O}$ in a new reaction chamber for atmospheric chemistry and physics, Environ. Sci. Technol., 39, 2668-2678, 2005.

Peng, C., Chan, M. N., and Chan, C. K.: The hygroscopic properties of dicarboxylic and multifunctional acids: Measurements and UNIFAC predictions, Environ. Sci. Technol, 35, 4495-4501, doi:10.1021/es0107531, 2001.

Petters, M. D. and Kreidenweis, S. M.: A single parameter representation of hygroscopic growth and cloud condensation nucleus activity, Atmos. Chem. Phys., 7, 1961-1971, doi:10.5194/acp-71961-2007, 2007.

Petters, M. D., Wex, H., Carrico, C. M., Hallbauer, E., Massling, A., McMeeking, G. R., Poulain, L., Wu, Z., Kreidenweis, S. M., and Stratmann, F.: Towards closing the gap between hygroscopic growth and activation for secondary organic aerosol - Part 2: Theoretical approaches, Atmos. Chem. Phys., 9, 3999-4009, doi:10.5194/acp-9-3999-2009, 2009.

Prenni, A. J., Petters, M. D., Kreidenweis, S. M., DeMott, P. J., and Ziemann, P. J.: Cloud droplet activation of secondary organic aerosol, J. Geophys. Res., 112, D10223, doi:10.1029/2006JD007963, 2007.

Raatikainen, T., Vaattovaara, P., Tiitta, P., Miettinen, P., Rautiainen, J., Ehn, M., Kulmala, M., Laaksonen, A., and Worsnop, D. R.: Physicochemical properties and origin of organic groups detected in boreal forest using an aerosol mass spectrometer, Atmos. Chem. Phys., 10, 2063-2077, doi:10.5194/acp-10-20632010, 2010

Saxena, P. and Hildemann, L. M.: Water absorption by organics: Survey of laboratory evidence and evaluation of UNIFAC for estimating water activity, Environ. Sci. Technol, 31, 3318-3324, 1997.

Shantz, N. C., Leaitch, W. R., and Caffreym P. F.: Effect of organics of low solubility on the growth rate of cloud droplets, J. Geophys. Res., 108, 4168-4177, doi:10.1029/2002JD002540, 2003.

Sjogren, S., Gysel, M., Weingartner, E., Alfarra, M. R., Duplissy, J., Cozic, J., Crosier, J., Coe, H., and Baltensperger, U.: Hygroscopicity of the submicrometer aerosol at the high-alpine site Jungfraujoch, $3580 \mathrm{~m}$ a.s.1., Switzerland, Atmos. Chem. Phys., 8, 5715-5729, doi:10.5194/acp-8-5715-2008, 2008.

Stokes, R. H. and Robinson, R. A.: Interactions in aqueous nonelectrolyte solutions. I. Solute-solvent equilibria, J. Phys. Chem., 70, 2126-2131, doi:10.1021/j100879a010, 1966.
Topping, D. O., McFiggans, G. B., and Coe, H.: A curved multicomponent aerosol hygroscopicity model framework: Part 1 - Inorganic compounds, Atmos. Chem. Phys., 5, 1205-1222, doi:10.5194/acp-5-1205-2005, 2005a.

Topping, D. O., McFiggans, G. B., and Coe, H.: A curved multicomponent aerosol hygroscopicity model framework: Part 2 Including organic compounds, Atmos. Chem. Phys., 5, 12231242, doi:10.5194/acp-5-1223-2005, 2005b.

Varutbangkul, V., Brechtel, F. J., Bahreini, R., Ng, N. L., Keywood, M. D., Kroll, J. H., Flagan, R. C., Seinfeld, J. H., Lee, A., and Goldstein, A. H.: Hygroscopicity of secondary organic aerosols formed by oxidation of cycloalkenes, monoterpenes, sesquiterpenes, and related compounds, Atmos. Chem. Phys., 6, 23672388, doi:10.5194/acp-6-2367-2006, 2006.

Virkkula, A., Van Dingenen, R., Raes, F., and Hjorth, J.: Hygroscopic properties of aerosol formed by oxidation of limonene, $\alpha$ pinene, and $\beta$-pinene, J. Geophys. Res., 104, 3569-3579, 1999.

Wilks, D.: Statistical methods in the atmospheric sciences, Academic Press, Elsevier, New York, 2006.

Wex, H., Petters, M. D., Carrico, C. M., Hallbauer, E., Massling, A., McMeeking, G. R., Poulain, L., Wu, Z., Kreidenweis, S. M., and Stratmann, F.: Towards closing the gap between hygroscopic growth and activation for secondary organic aerosol: Part 1 - Evidence from measurements, Atmos. Chem. Phys., 9, 3987-3997, doi:10.5194/acp-9-3987-2009, 2009.

Zhang, Q., Worsnop, D. R., Canagaratna, M. R., and Jimenez, J. L.: Hydrocarbon-like and oxygenated organic aerosols in Pittsburgh: insights into sources and processes of organic aerosols, Atmos. Chem. Phys., 5, 3289-3311, doi:10.5194/acp-5-32892005, 2005.

Zhang, Q., Jimenez, J. L., Canagaratna, M. R., Allan, J. D., Coe, H., Ulbrich, I., Alfarra, M. R., Takami, A., Middlebrook, A. M., Sun, Y. L., Dzepina, K., Dunlea, E., Docherty, K., DeCarlo, P. F., Salcedo, D., Onasch, T., Jayne, J. T., Miyoshi, T., Shimono, A., Hatakeyama, S., Takegawa, N., Kondo, Y., Schneider, J., Drewnick, F., Borrmann, S., Weimer, S., Demerjian, K., Williams, P., Bower, K., Bahreini, R., Cottrell, L., Griffin, R. J., Rautiainen, J., Sun, J. Y., Zhang, Y. M., and Worsnop, D. R.: Ubiquity and dominance of oxygenated species in organic aerosols in anthropogenically-influenced Northern Hemisphere midlatitudes, Geophys. Res. Lett., 34, L13801, doi:13810.11029/12007GL029979, 2007a.

Zhang, Q., Jimenez, J. L., Worsnop, D. R., and Canagaratna, M.: A case study of urban particle acidity and its influence on secondary organic aerosol, Environ. Sci. Technol., 41, 3213-3219, doi:10.1021/es061812j, 2007b. 